\title{
MDA levels in the pancreas, testes, liver, and plasma of diabetic rats: The effect of snakehead (Channa striata) extract
}

\author{
NURLITA ABDULGANI ${ }^{\vee}$, DEWI HIDAYATI, RESSY ADINOVITASARY, VARAH OLIVIATIE, \\ AYU DIAH SEKARTAJI \\ Department of Biology, Faculty of Science, Institut Teknologi Sepuluh Nopember. Campus ITS Sukolilo, Surabaya 60111, East Java, Indonesia \\ Tel.: +62-31-5963857, Fax.: +62-31-5963857, `email: nurlita@bio.its.ac.id
}

Manuscript received: 11 February 2019. Revision accepted: 18 February 2020

\begin{abstract}
Abdulgani N, Hidayati D, Adinovitasary R, Oliviatie V, Sekartaji AD. 2020. MDA levels in the pancreas, testes, liver, and plasma of diabetic rats: The effect of snakehead (Channa striata) extract. Nusantara Bioscience 12: 50-54. There are several biomarkers of oxidative stress in diabetes mellitus; one of those biomarkers is Malondialdehyde (MDA). Increasing oxidative stress will cause increased tissue damage. This study was conducted to determine the effect of snakehead extract (SHE) on MDA level of pancreas, testes, liver, and plasma of alloxan-induced diabetic rats. There were 5 groups of treatments: non-diabetic rats/negative control (C-), diabetic rats/positive control (C+), and 3 SHE level of administration: $1 \mathrm{~mL} /$ day (low dose/LD), $1.6 \mathrm{~mL} /$ day (middle dose/MD) and $2.1 \mathrm{~mL} / \mathrm{day}$ (high dose/HD). Alloxan-induced diabetic rats were administered with SHE extract orally every day for two weeks. The results showed that MDA levels in the testes, liver, pancreas, and plasma of diabetic rats administered with SHE and non-diabetic rats/negative controls (C-) were significantly lower ( $\mathrm{p}<0.05$ ) compared to MDA levels in the testes, liver, pancreas, and plasma of diabetic rats without SHE administration (positive control/C + ). The highest dose of SHE treatment $(2.1 \mathrm{~mL} /$ day) results in decreasing MDA levels were not significantly different $(\mathrm{p}>0.05)$ with the group of non-diabetic rats/negative controls $(\mathrm{C}-)$. The conclusion of this study was increasing SHE administration up to $2.1 \mathrm{~mL} /$ day result in reducing more of MDA levels in plasma, pancreas, liver, and testes of diabetic rats.
\end{abstract}

Keywords: Channa striata, diabetic rat, liver, MDA, pancreas, plasma, snakehead

\section{INTRODUCTION}

Diabetes is currently one of the biggest global health problems. The number of people with diabetes is increasing, now every 11 adults have one person with diabetes, and it is estimated that in 2040 every 10 adults will have one person with diabetes. The number of people with DM as many as 387 million in 2013 increased to 415 million in 2015 and is expected to increase to 642 million in 2046 (IDF 2015). Hyperglycemia in diabetes mellitus causes the formation of ROS (Reactive Oxygen Species). ROS can damage cell membranes when the double bond of unsaturated fatty acids in membranes bind to oxygen free radicals into lipid peroxide (Kumar et al. 2005). Lipid peroxidation is a chain phenomenon that results in the formation of various active compounds that cause cell damage. Increased oxidative stress will cause increased levels of tissue damage. Previous research by Wresdiati et al. (2015) showed that diabetic rats show structural damage in pancreas, liver, and testes (Wresdiati et al. 2015). Lipid peroxide is a free radical that can be a biomarker for oxidative stress in the body. Increased MDA levels are influenced by increased ROS production, so MDA is one marker to determine the presence of oxidative stress in cells (Tiwari et al. 2013).

According to National Fisheries data (2007), Snakehead fish (Channa striata) is the most abundant catch with $16.23 \%$ of a total of 15 species. Besides being popular in the community, both traditionally and scientifically, Snakehead fish shows the potential to be used as medicine.
These fish are traditionally used to heal wounds (Gam et al. 2005). The albumin extraction of Snakehead fish to produce protein (albumin) concentrate is expected to be a cheaper alternative source of albumin for clinical use (Asfar et al. 2014). Albumin is also reported to have antioxidant activity because it has a molecule that is capable of making multiple-binding sites and has free radical-trapping properties (Roche et al. 2008). A group ($\mathrm{SH}$ ) in albumin functions as a radical binder that plays a role in the cleaning process and inhibitory activities of Reactive Oxygen Species (Santoso 2009).

Preliminary research by Abdulgani et al. (2014) has proven that Snakehead fish extract (from now on abbreviated as SHE) has the potential to be a diabetes drug through the repair of the damaged pancreatic tissue structure. In hyperglycemic conditions, increased production of ROS that exceeds the antioxidant capacity of cells causes an increase in oxidative stress accompanied by dysfunction and damage to tissue cells (Palmeira et al. 2001; Kumar et al. 2005; Koya et al. In Forbes et al. 2008; Maslachah et al. 2008). Malondialdehyde (MDA) is widely used as a biomarker for assessing oxidative stress in the biomedical field. Biomonitoring MDA has been used both in-vivo and in-vitro studies as a key biomarker for various patterns of disease including diabetes (Singh et al. 2014). Malondialdehyde can be observed through the plasma, serum, and various tissues such as kidney tissue that has been reported in diabetic patients (Tiwari et al. 2013). Therefore, further research is needed to determine the 
MDA levels of various organs such as pancreas, testes, hepar and plasma after SHE treatment in diabetic rat.

\section{MATERIALS AND METHODS}

\section{Procedures}

Experimental animal

Wistar strain male rats aged 2 to 3 months with a body weight between 200-250 grams as many as 25 rats divided into 5 groups (5 rats in each group) namely (negative control) (C-), (positive control) (C+), LD (lower dose supplementation), MD (mid dose supplementation), and HD (high dose supplementation). Rats were acclimatized in the laboratory for two weeks. Cages are given husk evenly, and every day is given ad libitum food and drink. Rats were fasted for 8 hours before checking blood glucose levels on days 15,19 , and 34 .

\section{Snakehead fish extract preparation}

SHE production methods following several kinds of research which were conducted by Abdulgani et al. (2014) and Romadhoni et al. (2015). The snakehead fish is cleaned (scales, gills and stomach contents are removed) then washed and cut into small pieces. The meat mashed with a blender and added a solvent with a ratio of 1: 1 (100 $\mathrm{ml}$ of solvent and 100 grams of fish meat). The treatment in this study used a water solvent by heating $50^{\circ} \mathrm{C}\left(+10^{\circ} \mathrm{C}\right)$ for 15 minutes in a vacuum extractor. The sample is then filtered.

\section{Measurement of blood glucose}

Blood glucose level measurements of rats were carried out using Accu-Check ${ }^{\circledR}$ Active glucometer. Rat blood glucose levels were measured three times, before induction (day 15), after induction of alloxan monohydrate (day 19), and after administration of SHE (day 34).

Blood glucose measurements of rats were carried out after rats fasted for 12-18 hours (Butler 1995). Blood collection is done through the mouse tail. The tail of the rat is cleaned first using $70 \%$ alcohol, followed by cutting the tip of the tail until the blood comes out from the tip of the tail. The blood that is released then drops as much as one drop on the glucose strip that has been inserted into the glucometer and waited until the blood glucose level $(\mathrm{mg} / \mathrm{dL})$ is displayed on the glucometer screen.

\section{Diabetes mellitus induction by Alloxan}

The rats were weighed to find out the initial body weight to determine the amount of alloxan monohydrate that would be induced. Induction of alloxan monohydrate is carried out intraperitoneally. The dosage of alloxan monohydrate induction refers to Oghenesuvwe (2014) which is $150 \mathrm{mg} / \mathrm{kg}$ body weight of rats, using $0.9 \% \mathrm{NaCl}$. The stock solution of alloxan monohydrate was carried out by dissolving $1200 \mathrm{mg}$ of alloxan monohydrate (SigmaAldrich) in $16 \mathrm{ml}$ of $0.9 \% \mathrm{NaCl}$. Induction of alloxan monohydrate was carried out on the 15th day, after checking the initial blood glucose level.

Induction was performed on rats in the Positive Control $(\mathrm{C}+)$, Low Dose (LD), Middle Dose (MD) and High Dose
(HD) groups. Negative Control (C-) group of rats was only injected with pre-injection distilled water. Each rat was induced by $0.4 \mathrm{~mL}$ alloxan monohydrate, using a $1 \mathrm{~mL}$ syringe intraperitoneally. First, the ventral part of the rat's body is rubbed with cotton that has been moistened with $70 \%$ alcohol to be sterile. Then the syringe that contains alloxan solution injected into the area. Checking blood glucose levels is done 48-72 hours after injection. Rat with blood glucose levels $\geq 200 \mathrm{mg} / \mathrm{dL}$ are classified as hyperglycemia (Lenzen 2007).

\section{Experiment design}

Rats with blood glucose levels of 200-400 mg/dL and grouped in LD, MD and HD were treated with SHE orally for two weeks with the following doses:

LD group: given SHE at a dose of $1 \mathrm{~mL} /$ day

MD group: given $\mathrm{SHE}$ at a dose of $1.6 \mathrm{~mL} /$ day

HD group: given SHE at a dose of $2.1 \mathrm{~mL} /$ day.

SHE was administered daily for 14 days, which is until the $33^{\text {rd }}$ day from day $19^{\text {th }}$ to day $33^{\text {rd }}$. The dose of SHE given to hyperglycemic rat refers to research conducted by Abdulgani et al. (2014).

\section{Plasma and rat organ sampling}

At the end of the experiment, the rats were sacrificed and euthanized using ketamine $\mathrm{HCl} 0.2 \mathrm{cc} / \mathrm{gram}$. Blood collected using a $3 \mathrm{~mL}$ syringe. The blood is put into EDTA containing tube. Blood was centrifuged at $3000 \mathrm{rpm}$ at $37^{\circ} \mathrm{C}$ for 15 minutes to separate plasma and the blood cell. Plasma (top layer) is used for MDA analysis. The pancreas, liver, and testes were excised, washed with $0.9 \%$ $\mathrm{NaCl}$ solution. Each organ is divided into two parts wherein $1 / 4$ the part was placed in Paraformaldehyde (PFA) $10 \%$ solution, and $3 / 4$ part was placed in a solution of Phosphate Buffer Saline-Azide (PBS-azide) pH 7.4. These organs will be analyzed for malonaldehyde (MDA) levels.

\section{Malondialdehyde (MDA) measurements in the pancreas, liver, and testes of diabetic rats}

0.5 gram of pancreas, liver, and testes organs are taken and put in a tissue grinder. The treatment of each organ includes several stages, including $4.5 \mathrm{ml}$ cold PBS solution was added. After the organ has been mashed, the solution was centrifuged at $3000 \mathrm{rpm}$ for 15 minutes. $4 \mathrm{ml}$ supernatant was taken, then $1 \mathrm{ml}$ of Trichloroacetic Acid (TCA) $15 \%$ solution was added. Furthermore, given $1 \mathrm{ml}$ of $0.37 \%$ TBA solution in $0.25 \mathrm{~N} \mathrm{HCl}$, and then heated in a water bath at 80 o $\mathrm{C}$ for 15 minutes, then cooled to room temperature for 60 minutes. Then the solution was centrifuged at $3000 \mathrm{rpm}$ for 15 minutes. MDA supernatant absorbance measurements were taken using a spectrophotometer with a wavelength of $532 \mathrm{~nm}$. After the absorbance value is obtained, MDA levels are then calculated using the regression line equation from the standard curve of the standard MDA solution (Hermiyanti, et al. 2015).

\section{Malondialdehyde (MDA) plasma measurement}

Blood plasma as much as $500 \mu \mathrm{L}$ was transferred into a centrifuge tube containing $4.5 \mathrm{~mL}$ of cold PBS solution. 
Blood plasma in PBS was added with $1 \mathrm{~mL}$ of $15 \%$ TCA solution, $1 \mathrm{~mL}$ of $0.37 \%$ TBA solution which was dissolved in $0.25 \mathrm{~N} \mathrm{HCl}$. The mixture was homogenized with vortex and then heated in a water bath at $80 \mathrm{oC}$ for 15 minutes. The mixture was cooled to room temperature for 60 minutes, followed by centrifugation at $3000 \mathrm{rpm}$ for 15 minutes. The absorbance of supernatant for MDA determination was measured at $532 \mathrm{~nm}$. After obtaining the absorbance value, MDA levels were then calculated using the regression equation from the standard MDA standard solution (Hermiyanti et al. 2015).

\section{Data analysis}

This research is conducted using a Completely Randomized Design (CRD). Rats are divided into five groups with each group had five repetitions. Statistical analysis was performed quantitatively using one-way analysis of variance (ANOVA) and followed by Tukey's test. $\mathrm{P}$-values less than 0.05 were considered significant.

\section{RESULTS AND DISCUSSION}

\section{Result}

The results in Table 1 showed that MDA levels in plasma, testis, pancreas, and liver of diabetic rats without SHE treatment $(\mathrm{C}+)$ were higher than plasma, testis, and pancreas of diabetic rats treated with SHE (LD, MD, and $\mathrm{HD})$ and non-diabetic rats (negative control (C-)/normal rats.

Decreasing MDA level in diabetic rats treated with SHE might be caused by the antioxidant properties of SHE. The results of statistical tests using One Way ANOVA showed that the average MDA levels of plasma, liver, and pancreas in diabetic rats in all treatments of SHE (LD, MD, and HD) were significantly lower $(p<0.05)$ than the average level of MDA in plasma, liver, and pancreas of diabetic rat $(\mathrm{C}+)$ without SHE treatment (Table 2 and figures $1 \mathrm{a}, 1 \mathrm{~b}, 1 \mathrm{c})$. Whereas in the testes, only high dose (HD) of SHE treatment showed an average MDA level was significantly lower $(\mathrm{p}<0.05)$ than a diabetic rat $(\mathrm{C}+)$ (figure $1 \mathrm{~d})$.

\section{Discussion}

Antioxidant capacity of SHE in the diabetic rats used in this study was indicated by Malondialdehyde (MDA) concentration. MDA is a free radical produced by reactive lipid peroxidation metabolites and is commonly used as a biomarker of lipid peroxidation to determine oxidative stress (Shofia et al. 2013). The results showed that the MDA levels of plasma, testes, liver, pancreas in diabetic rats $(\mathrm{C}+)$ were higher than the MDA levels of plasma, testes, liver, pancreas in the group of normal, non-diabetic rats (C-). Previous studies showed that MDA levels of alloxan-induced diabetic rats in the pancreas (Elkotby et al. 2018), plasma, liver (Aluwong et al. 2016) and testes (Roy et al. 2015) were significantly higher than the control group. This shows that alloxan can trigger the formation of ROS in the plasma, testes, liver, pancreas.

Alloxan is a chemical compound synthesized by very unstable pyrimidine derivative. Alloxan works through two different mechanisms in inducing diabetes mellitus (DM), namely the mechanisms of selectively inhibiting glucoseinduced insulin secretion through special inhibition of glucose sensors in B (glucokinase) cells, and inducing the formation of ROS (Reactive Oxygen Species) that causes selective cell necrosis of pancreatic $\beta$ cells and induces insulin resistance (Lenzen 2007). Several studies show that experimental animals with high blood glucose levels (hyperglycemia) or humans with DM result in increased oxidative stress in several organs, including; liver (Lailatul et al. 2015), testicles (Roy et al. 2015) and plasma (Fajrilah et al. 2013).

MDA levels in the pancreas and testes showed a higher level compared to plasma and liver of the alloxan-induced diabetic rat. This is because Alloxan toxic glucose analogs that specifically accumulate in pancreatic beta cells via the GLUT2 glucose transporter. In the presence of intracellular thiols, especially glutathione, alloxan generates reactive oxygen species (ROS) in a cyclic redox reaction with its reduction product, dialuric acid. Autoxidation of dialuric acid generates superoxide radicals, hydrogen peroxide and, in a final iron-catalyzed reaction step, hydroxyl radicals. The hydroxyl radicals are ultimately responsible for the death of the beta cells, which have a particularly low antioxidative defense capacity, and a further state of insulin-dependent 'alloxan-induced diabetic' (Lenzen 2007).

Glut2 glucose transporters are also found in testicular cells of rat (Kokk et al. 2004) Therefore, MDA levels in the testes are also higher as in the pancreas of diabetic rats. Momuat et al. (2011) stated that the MDA level in the plasma is a potential indicator of oxidative stress. Aluwong et al. (2016) showed that hyperglycemia was accompanied by increased lipid peroxidation, as proven by the significant increase of MDA concentration in the serum of untreated diabetic rats. The increase of serum MDA concentration in the untreated diabetic rats may be associated with the destruction of erythrocytic membranes and tissues, caused by the oxidative stress.

Table 1. MDA levels in the plasma, liver, pancreas, and testes of diabetic rats after SHE treatment

\begin{tabular}{lcccc}
\hline \multirow{2}{*}{ Treatment } & \multicolumn{4}{c}{ Level of MDA (mmol/ml) } \\
\cline { 2 - 5 } & Plasma & Liver & Pancreas & Testis \\
\hline C- & $2.01 \pm 1.028$ & $33.62 \pm 1.983$ & $12.23 \pm 3.084$ & $55.31 \pm 3.529$ \\
C+ & $6.54 \pm 1.690$ & $38.81 \pm 5.107$ & $93.96 \pm 5.502$ & $99.95 \pm 14.625$ \\
LD & $3.74 \pm 0.550$ & $29.49 \pm 4.693$ & $52.29 \pm 27.108$ & $88.64 \pm 8.235$ \\
MD & $2.58 \pm 0.867$ & $31.23 \pm 1.987$ & $33.43 \pm 3.375$ & $84.27 \pm 8.903$ \\
HD & $2.04 \pm 0.498$ & $24.11 \pm 1.029$ & $23.99 \pm 1.247$ & $71.43 \pm 5.329$ \\
\hline
\end{tabular}

Note: C-: Non-diabetic rat (C-), Diabetic rats without SHE (Snakehead extract) treatment $(\mathrm{C}+$ ), Low Dose SHE treatment $=1.0 \mathrm{~mL} / \mathrm{day}$ $(\mathrm{LD})$, Middle dose SHE treatment $=1.6 \mathrm{~mL} /$ day $(\mathrm{MD})$, High Dose SHE treatment $=2.1 \mathrm{~mL} /$ day $(\mathrm{HD})$ 

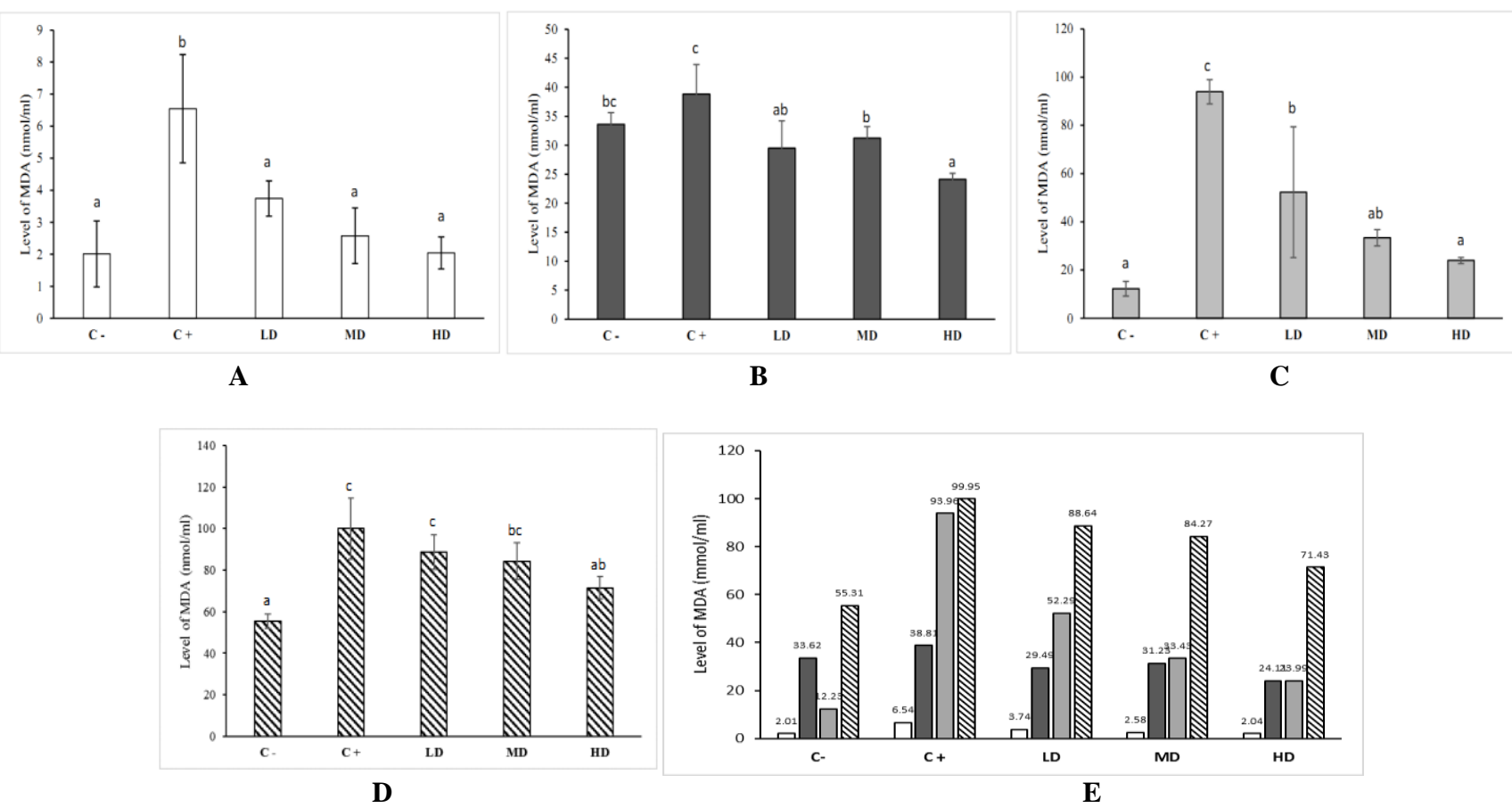

Figure 1. MDA Levels Graph: (A) plasma, (B) liver, (C) pancreas, (D) testis, and (E) the comparison of MDA level from different organs. (C-) Diabetic rats without SHE (Snakehead extract) treatment $(\mathrm{C}+)$, Low Dose SHE treatment $=1,0 \mathrm{ml} / \mathrm{day}(\mathrm{LD})$, Middle dose SHE treatment $=1,6 \mathrm{ml} /$ day $(\mathrm{MD})$, High Dose $\mathrm{SHE}$ treatment $=2,1 \mathrm{ml} /$ day $(\mathrm{HD})$

Snakehead Extract (SHE) has the ability as an antioxidant due to the content of essential amino acids and fatty acids content of the meat of snakehead fish. In general, fish is an important source of antioxidant and snakehead fish is one of the main freshwater fishes which c have antioxidant activity. Its antioxidant activity of snakehead fish was contributed by the amino acids and fatty acids (Hannifa et al. 2014). Fish produce more of lipophilic antioxidants which effectively acts against the oxidation of omega 3 . The amino acids are known to have significant antioxidant properties as synergists or primary antioxidants and believed to be important metal chelates with significant potential in linoleic acid and methyl esters linoleic acid system. The in-vitro antioxidant activity of Channa sp. was higher than in other fish as seen from DPPH radical scavenging and ferric reducing power (Hannifa et al. 2014). Narsing et al. (2012showed that the antioxidant capacity of snakehead fish was high with inhibition percentage of $56.7 \pm 1.21 \% / 10 \mathrm{mg}$ of crude protein concentrate.

Antioxidant activity of protein is influenced by its structure, namely; molecular weight, and amino acids with free atoms (-H), including His (histidine), Trp (Tryptophan), Phe (phenylalanine)), Pro (Proline), Gly (Glycine), Lys (lycine), Ile (Isoleucine) and Val (Valine) (Zou et al., 2016). According to Gam et al (2005), snakehead fish has several amino acids, including; His $(2,772-2,857 \mathrm{~g} / 100 \mathrm{~g}$ protein), Phe $(4,734-4,854 \mathrm{~g} / 100 \mathrm{~g}$ protein), Pro (3,618-3,77 g/100g protein), Gly (4,815-5,024 $\mathrm{g} / 100 \mathrm{~g}$ protein), Lys (8.8-9.02 g/100g protein), Ile (4.77$5.03 \mathrm{~g} / 100 \mathrm{~g}$ protein) Val $(4,892-5,128 \mathrm{~g} / 100 \mathrm{~g}$ protein). Furthermore, Gam et al. (2005) showed that Cys content in snakehead fish was higher $(0.93-1.203 \mathrm{~g} / 100 \mathrm{~g}$ protein) compared to salmon $(0.8-0.95 \mathrm{~g} / 100 \mathrm{~g}$ protein). Albumin contains high amounts of cysteine which serves free radical binding site at thiol (-SH) functional group. In addition, based on molecular weight, albumin is composed of amino acids with a molecular weight of 1300-1400 Da (Merrel et al., 2004). Proteins composed of amino acids with a molecular weight of 1300-1400 Da can significantly increase their antioxidant activity (Huy et al., 2014). This can be an indication that albumin has a role as an antioxidant properties but the exact mechanism of antioxidant activity of peptides is not yet fully understood (Sarmadi et al. 2010), Nevertheless, the previous studies have shown that peptides are able to act as; lipid peroxidation inhibitors, scavengers of free radicals and chelators of transition metal ions (Najafian et al. 2012; Zou et al. 2016).

The average of MDA concentration in plasma, liver, pancreas, and testes of diabetic rats treated with SHE (HD, $\mathrm{MD}$, and LD) was significantly lower $(\mathrm{p}<0.05)$ than plasma MDA concentrations in hyperglycemic rats not treated with SHE $(\mathrm{C}+)$. Lowering MDA levels on SHE treatment of diabetic rats indicate that SHE administration increase antioxidant capacity, therefore, reducing levels of free radicals or oxidative stress in plasma, liver, pancreas, and testicles of diabetic rat. This result was in accordance with the previous study by Abdulgani (2013) that SHE treatment resulted in better pancreatic tissue of hyperglycemic rats compared to without SHE treatment in diabetic rats. Therefore, SHE might also have the potential in restoring function/structure of blood tissue, and testes as found in the pancreas. In general, it can be stated that the 
higher the EIG administration, the higher the antioxidant capacity in blood plasma, pancreas, liver, and testes. This indicates that EIG also has the potential to restore function/tissue structure to normal conditions. The liver produces catalase enzyme which has antioxidant activity so that the high content of catalase in the liver reduces oxidative stress in the liver of hyperglycemic rat. As a result, MDA concentration in the liver of diabetic rat is the same as a normal rat (Kikumoto et al. 2009). The MDA level in liver of diabetic rat treated with SHE manifest its capacity to strengthened antioxidant activity of catalase. The conclusion of the study was the higher the level of SHE administration, the lower the level of MDA in the plasma, pancreas, liver, and testes.

\section{ACKNOWLEDGEMENTS}

This research is financially supported by a grant from Institut Teknologi Sepuluh Nopember (ITS) Research Center.

\section{REFERENCES}

Abdulgani N. 2013. Teknik peningkatan produksi albumin dari ekstrak ikan gabus (Channa striata) dan pengembangan potensinya sebagai obat diabetes. Jurusan Biologi FMIPA ITS, Surabaya. [Indonesian]

Abdulgani N, Trisnawati I, Aunurohim, Hidayati D, Aisyatussoffi N, Arifiyanto A. 2014. Snakehead (Channa striata) extracts treatment towards hyperglycemic mice (Mus musculus) blood glucose levels and pancreatic histology structure. J Appl Envir Biol Sci 4 (5): 1-6.

Aluwong T, Ayo JO, Kpukple A, Oladipo OO. 2016. Amelioration of hyperglycaemia, oxidative stress and dyslipidaemia in alloxaninduced diabetic Wistar rats treated with probiotics and vitamin $\mathrm{C}$. Nutrients 8(5): 151.

Asfar M, Tawali AB, Abdullah N, Mahendradatta. M. 2014. Extraction of albumin of snakehead fish (Channa striatus) in producing the Fish Protein Concentrate (FPC). Intl J Sci Technol Res 3(4): 85-88.

Elkotby D, Hassan AK, Emand R, Bahgat I. 2018. Histological changes in islets of Langerhans of pancreas in alloxan-induced diabetic rats following Egyptian honey bee venom treatments. Intl J Pure Appl Zool 6 (1): 1-6.

Fajrilah BR, Indrayani UD, Djam'an Q. 2013. Pengaruh pemberian madu terhadap kadar malondialdehyde (MDA) plasma darah pada tikus yang diinduksi alloxan. Sains Medika 5 (2): 98-100. [Indonesian]

Gam LHCY, Leow S, Baie S. 2005. Amino acid composition of snakehead fish (Channa striatus) of various sizes obtained at different times of the year. Malaysian J Pharm Sci 3: 19-30.

Hannifa MAK, Sheela PAJ, Kavitha K, Jais AMM. 2014. Salutary value of haruan, the striped snakehead Channa striatus. A review. Asian Pac J Trop Biomed 4 (Suppl 1): S8-S15.

Hermiyanti P, Mukono HJ, Notopuro H. 2015. Lipid peroxidation and respiratory disorders to the workers pool. Intl J Sci Res Mgmt 3 (7): 3301-3304.

IDF Diabetes Atlas 7th Edition. 2015. International Diabetes Federation. (https://www.idf.org/e-library/epidemiology.../13-diabetes-atlasseventh-edition.html.)
Kikumoto. 2009. http://www.scientificamerican.com/article/bring-sciencehome-liverhelping-enzymes/

Kokk K, Veräjänkorva E, Wu XK, Tapfer H, Põldoja E, Pöllänen P. 2004. Immunohistochemical detection of glucose transporters class $\mathrm{i}$ subfamily in the mouse, rat and human testis. Medicina (Kaunas) 40 (2): 156-160.

Kumar V, Abdul KA, Nelson F. 2005. Robbins and Cotran Pathologic Basis of Disease. $7^{\text {th }}$ ed. Elsevier Sauders, Philadelphia.

Lailatul NF, Lyrawati D, Handaru M. 2015. Effect of alpha lipoic acid administration on mda levels and liver histology of male wistar rats with type 1 diabetes mellitus. Jurnal Kedokteran Brawijaya 28(3): 170-176. [Indonesian]

Lenzen S. 2007. The Mechanisms of alloxan and streptozotocin-induced diabetes. Diabetologia 51: 216-226.

Maslachah L, Sugihartuti R, Kurniasanti R. 2008. Hambatan produksi reactive oxygen species radikal superoksida (O2-) oleh antioksidan vitamin E ( $\alpha$-Tocopherol) pada tikus putih (Rattus norvegicus) yang menerima stressor renjatan listrik. Media Kedokteran Hewan 24 (1): 21-26. [Indonesian]

Merrell K, Southwick K, Graves SW, Esplin MS, Lewis NE, Thulin CD. 2004. Analysis of low-abundance, low-molecular-weight serum proteins using mass spectrometry. J Biomol Tech 15 (4): 238-248.

Momuat LI, Sangi MS, Purwati NP. 2011. Pengaruh Vco mengandung ekstrak wortel terhadap peroksidasi lipid plasma. Jurnal Ilmiah Sains 11 (2): DOI: 10.35799/jis.11.2.2011.222. [Indonesian]

Najafian L, Babji AS. 2012. A review of fish-derived antioxidant and antimicrobial peptides: Their production, assessment, and applications. Peptides 33 (1): 178-85.

Narsing RG, Balaswamy K, Satyanarayana A, Prabhakara RP. 2012. Physicochemical, amino acid composition, functional and antioxidant properties of roe protein concentrates obtained from Channa striatus and Lates calcarifer. Food Chem 132 (3): 1171-1176.

Oghenesuvwe EE, Ekene NE, Ajaghaku, DL. 2014. Guidelines on dosage calculation and stock solution preparation experimental animals studies. J Nat Sci Res 4 (18): 100-106.

Roche M, Rondeau P, Singh NR, Tarnus E, Bourdon E. 2008. The antioxidant properties of serum albumin. FEBS Lett 582 (Issue 13): 1783-1787.

Roy VK, Chenkual L, Gurusubramanian G. 2015. Protection of testis through antioxidant action of Mallotus roxburghianu in alloxaninduced diabetic rat model. J Ethnopharmacol 176: 268-280.

Santoso AH. 2009. Potensi ekstrak ikan gabus (Channa striata) sebagai hepatoprotector pada tikus yang diinduksi dengan parasetamol. [Thesis]. Institut Pertanian Bogor, Bogor. [Indonesian]

Sarmadi BH, Ismail A. 2010. Antioxidative peptides from food proteins: A review 31 (10): 1949-1956.

Shofia V, Aulanni'am, Mahdi C. 2013. Studi pemberian ekstrak rumput laut coklat (Sargassum prismaticum) terhadap kadar malondialdehid dan gambaran histologi jaringan ginjal pada tikus (Rattus norvegicus) diabetes melitus tipe 1. Jurnal Ilmu Kimia Universitas Brawijaya 1: 119-125. [Indonesian]

Singh VP, Bali A, Singh N, Jaggi AS. 2014. Advanced glycation end products and diabetic complications. Korean J Physiol Pharmacol 18 (1): 1-14.

Tiwari BK, Pandey KB, Abidi AB, Rizvi SI. 2013. Marker oxidative stress during diabetes mellitus. J Biomark 378790: 1-8.

Wresdiyati T, Karmila A, Astawan M, Karnila R. 2015. Teripang pasir meningkatkan kandungan antioksidan superoksida dismutase pada pankreas tikus diabetes. Jurnal Veteriner 16 (1): 145-151. [Indonesian]

Zou TB, He TP, Li HB, Tang HW, Xia EQ. 2016. The structure-activity relationship of the antioxidant peptides from natural proteins. Molecules 21 (1):72. DOI: 10.3390/molecules21010072 